\title{
Silvicultural strategies for increased timber harvesting in a Central European mountain landscape
}

\author{
Christian Temperli $^{1}$ (D) $\cdot$ Golo Stadelmann ${ }^{1} \cdot$ Esther Thürig $^{1} \cdot$ Peter Brang $^{1}$
}

Received: 12 July 2016/Revised: 30 March 2017/Accepted: 5 April 2017/Published online: 9 April 2017

(C) Springer-Verlag Berlin Heidelberg 2017

\begin{abstract}
The demand for wood as construction material, renewable source for energy and feedstock for chemicals is expected to increase. However, timber increments are currently only partly harvested in many European mountain regions, which may lead to supply shortages for local timber industries, decreases in forest resistance to disturbances and functioning as protection from gravitational hazards. Using an inventory-based forest simulator, we evaluated scenarios to increase wood mobilization in the $7105-\mathrm{km}^{2}$ Swiss canton of Grisons for the period 2007-2106. Scenarios varied with respect to landscapescale harvesting amounts and silvicultural strategies (low vs. high stand-scale treatment intensity) and accounted for regulations and incentives for protection forest management. With 50 and $100 \%$ increases of harvests, the current average growing stock of $319 \mathrm{~m}^{3} \mathrm{ha}^{-1}$ was simulated to be reduced by 12 and 33\%, respectively, until 2106 in protection forests of Northern Grisons, where management is prioritized due to subsidies. Outside protection forests and in Southern Grisons, growing stock was simulated to continually increase, which led to divergent developments in forest structure in- and outside protection forests and in the Northern and Southern Grisons. The effect of silvicultural strategies on simulated forest structure was small
\end{abstract}

Communicated by Christian Ammer.

Electronic supplementary material The online version of this article (doi:10.1007/s10342-017-1048-1) contains supplementary material, which is available to authorized users.

Christian Temperli

christian.temperli@wsl.ch

1 Swiss Federal Institute for Forest, Snow and Landscape Research WSL, 8903 Birmensdorf, Switzerland compared to the effect of future harvesting levels. We discuss opportunities and threats of decreasing management activities outside protection forests and advocate for incentives to promote natural regeneration also outside protection forests to safeguard long-term forest stability.

Keywords Empirical forest model MASSIMO - Forest inventory · European Alps · Protection forest · Timber mobilization $\cdot$ Scenario analysis

\section{Introduction}

Wood can make a significant contribution to reducing $\mathrm{CO}_{2}$ emissions by replacing more energy-intensive construction materials such as concrete and steel and by substituting fossil fuel-based products in industrial and pharmaceutical production and in energy generation (Dodoo et al. 2012; Werner et al. 2010). European and many national policies support research and development activities for innovative wood-based products and technologies and engage in the forestry sector and the wood-based industries with regulations, subsidies and financial compensations for nonmarket forest ecosystem services (Federal Office for the Environment 2013; Nabuurs et al. 2015). As a result, the demand for wood is expected to increase in forthcoming decades (Ferranti 2014; Kraft 2015; Lauri et al. 2012). On the supply side, opposite trends are being observed in many Central European mountain regions (Forest Europe et al. 2011). For instance, only $2.7 \mathrm{~m}^{3} \mathrm{ha}^{-1}$ year $^{-1}$ (53\%) of the $5.1 \mathrm{~m}^{3} \mathrm{ha}^{-1}$ net annual growth was used, i.e., extracted with logging operations, between 1993 and 2013 in Swiss Alpine forests (Fischer and Camin 2015). Reasons include poor accessibility that lead to high harvesting costs in difficult mountainous terrain and decreasing prices for 
sawtimber, making harvesting timber in this mountain region unprofitable (Fischer and Camin 2015; Kläy 2015).

As increment was only partially harvested in the past decades, growing stock continued to build up in Swiss mountain regions (Abegg et al. 2014; Camin et al. 2015). The increasing abundance of old and large trees may increase forest susceptibility to windthrow and mortality due to bark beetles and other pathogens (Pasztor et al. 2014; Seidl et al. 2011c; Usbeck et al. 2010). Increasing stand density and canopy closure decreases light availability and may hamper natural regeneration that makes the forests resilient to disturbance by ensuring that disturbed patches are restocked fast and continue to provide ecosystem services (Kupferschmid and Bugmann 2005; Royo and Carson 2006).

Disturbance-induced tree mortality and regeneration failures may seriously compromise the provision of protective services against avalanches, rockfall and landslides (Bebi et al. 2009; Brang et al. 2004). Tree stems are obstacles to falling rocks, and a snow intercepting canopy prevents the buildup of a homogenous snow layer that could be released as a slab avalanche. The protective effect against rockfall, for example, increases, inter alia, with increasing stand density and tree diameters (Dorren et al. 2005), but dense stands exhibit low resistance to disturbance and low resilience. To balance a high protective effect with high resistance and resilience, regular management interventions are required. Thinning and gap cutting that improve light conditions for regeneration and promote the stability of the remaining trees can be used to ensure forest stability and a continuous protection in the long term (Brang et al. 2006; Frehner et al. 2005).

Forest growth models are powerful tools for scenario analyses to develop and evaluate forest management strategies that aim at both increased timber mobilization and maintain the forest's protection function (Pretzsch et al. 2008). Previous stand-scale modeling studies in Central European mountain forests have identified benefits of intensified management in terms of long-term forest stability, resistance and resilience to disturbance (Maroschek et al. 2014; Seidl et al. 2011a). Rammer et al. (2015) presented a scenario of protection forest management that outperforms a business-as-usual shelterwood and a no-management strategy in terms of both the long-term protective effect and the harvesting revenues. Regionaland country-scale, inventory-based forest growth modeling studies argued that intensified management may foster the substitution of fossil fuel intensive construction materials, yet with the drawback of a reduced carbon sink (Thürig and Kaufmann 2010) and high harvesting costs, particularly in mountain regions (Stadelmann et al. 2016). Inventorybased forest simulators combine the advantage of comparably accurate representation of the initial forest state over a large area (e.g., countries and regions) with empirically grounded models of forest growth, mortality and regeneration (Barreiro et al. 2016). However, scenario analyses with inventory-based forest models have so far not explicitly accounted for the effects of regulations and incentives for protection forest management. These include restrictions on the size of openings and federal and cantonal subsidies. Such interventions from government bodies may be important for long-term forest development under scenarios of increased timber mobilization, particularly in Switzerland. In this country, a large part of mountain forest management concentrates on protection forests and is made possible by subsidies for otherwise unprofitable operations.

Governmentally subsidized protection forest management may tie up limited labor capacity with the consequence of forest management activities being restricted to protection forests. We hypothesize that this may lead to diverging forest developments in- and outside protection forests. Timber mobilization may be increased by allocating labor either to a large yearly area treated, i.e., decreasing the cutting cycle, or to a smaller area with higher treatment intensity. With an increase in treated area, forest stability and its protection effect may be enhanced for a larger part of the forest area within a shorter period of time. An increase in treatment intensity, in contrast, may be more efficient if timber harvesting is the main management goal. We expect these strategies to affect developments in forest structure differently. Both increases in timber mobilization and a larger treated area may require more management in remote areas and steep slopes and therefore higher expenses for harvesting operations.

To address these hypotheses, we assessed the long-term consequences of increased timber mobilization for forest development in- and outside protection forests by simulating forest development for the Alpine Swiss canton of Grisons using the inventory-based, empirical single-tree model MASSIMO (Kaufmann 2001a). While we explicitly accounted for management incentives and regulations in protection forests, we considered forest management scenarios that varied with respect to timber harvesting targets (50, 100 and 300\% increases of current harvests) and management strategies that in turn varied with respect to the yearly treated area and the stand-scale treatment intensity. Specifically, we asked (1) how increases in timber harvest influence forest development in terms of growing stock (standing volume), future forest growth (volume increment) and the volume of mortality and how these developments differ in- and outside protection forests, (2) how scenarios of increased timber harvesting and varying management strategies affect long-term forest structure and (3) harvesting costs. 


\section{Methods}

\section{Study area and data}

The Canton of Grisons was selected as study area as it represents environmental and socioeconomic conditions in large parts of Central European mountain regions such as the Alps and Carpathians. This canton encompasses an area of $7105 \mathrm{~km}^{2}$, of which $2008 \mathrm{~km}^{2}$ are forested. Our analyses are based on the data of the second and third Swiss national forest inventory (NFI2 1993/95, NFI3 2004/06; Brändli 2010). The Grisons comprise 698 accessible, permanently stocked sample plots, of which $90 \%$ are located between 745 and 2037 meters above sea level (median: $1521 \mathrm{~m}$ a.s.l.). In total, 8203 trees were recorded in two concentric circles: Trees $12-36 \mathrm{~cm}$ in diameter at breast height $(\mathrm{dbh})$ were recorded on a $200-\mathrm{m}^{2}$ circle and trees $>36 \mathrm{~cm} \mathrm{dbh}$ on a $500-\mathrm{m}^{2}$ circle. Young trees $<12 \mathrm{~cm} \mathrm{dbh}$ and $>10 \mathrm{~cm}$ in height were recorded on each sample plot in two $14 \mathrm{~m}^{2}$ subplots (Stierlin and Zinggeler 2001). Norway spruce (Picea abies [L.] H. Karst., 49\%), European larch (Larix decidua Mill., 13\%) and Scots pine (Pinus silvestris L., $6 \%$ ) dominate the subalpine and montane forest area in Grisons. Forest area dominated by broadleaves decreases with elevation from $3 \%$ above $1400 \mathrm{~m}$ a.s.l. to $12 \%$ below $1400 \mathrm{~m}$ a.sl. and is with $28 \%$ higher in the part of Grison belonging to the NFI production region Southern Alps (henceforth termed Southern Grisons: Valle di Poschiavo and Val Mesolcina) than the $9 \%$ in the production region Alps (Northern Grisons, Fig. 1; Table 1) (Ellenberg 1996;
Traub et al. 2017). Forest management includes both commercial harvests and protection forest management by means of thinning and group selection cuttings, often using cable yarders. Harvesting and mortality together amounted to almost half of the total volume increment between NFI2 and NFI3 in Northern Grisons and to less than $10 \%$ of the increment in Southern Grisons. The low volumes of harvested timber in the Southern Alps have persisted for decades because of poor accessibility (percent forest area with $\log$-hauling distance to nearest landing $>1000 \mathrm{~m}$ is $50 \%$ in Southern Grisons and 33\% in Northern Grisons) and steep terrain that make most management activities unprofitable (Stadelmann et al. 2015; Traub et al. 2017). We account for these regional differences in forest management by stratifying our analyses for Northern and Southern Grisons.

The latest delineation of Grisons' protection forest perimeter ("Neuer Schutzwald Graubünden 2012") encompasses 446 (64\%) of the 698 NFI sample plots in Grisons and differentiates between three types of protection forests: protection of high damage potential (e.g., forest above settlement: type A); protection of smaller damage potential (e.g., road in side valley: type B) and forest areas where protection management focuses on the prevention of log jams in stream channels (type C). In this study, we only consider protection forest types A and B (respectively, $34 \%$ and $10 \%$ of forest area) because only in these types significant parts of the forest area are managed. In type C (23\%), interventions to prevent log jams are limited to stream beds (Wilhelm et al. 2011).
Fig. 1 Distribution of sample plots in the study area (Canton of Grisons). The inset map shows the Canton of Grisons within Switzerland in black. Sample plots within and outside the perimeter of protection forest types A and B are indicated with red and purple points, respectively.

Background colors indicate the NFI production regions (beige

Northern Grisons; green

Southern Grisons). (Color figure online)

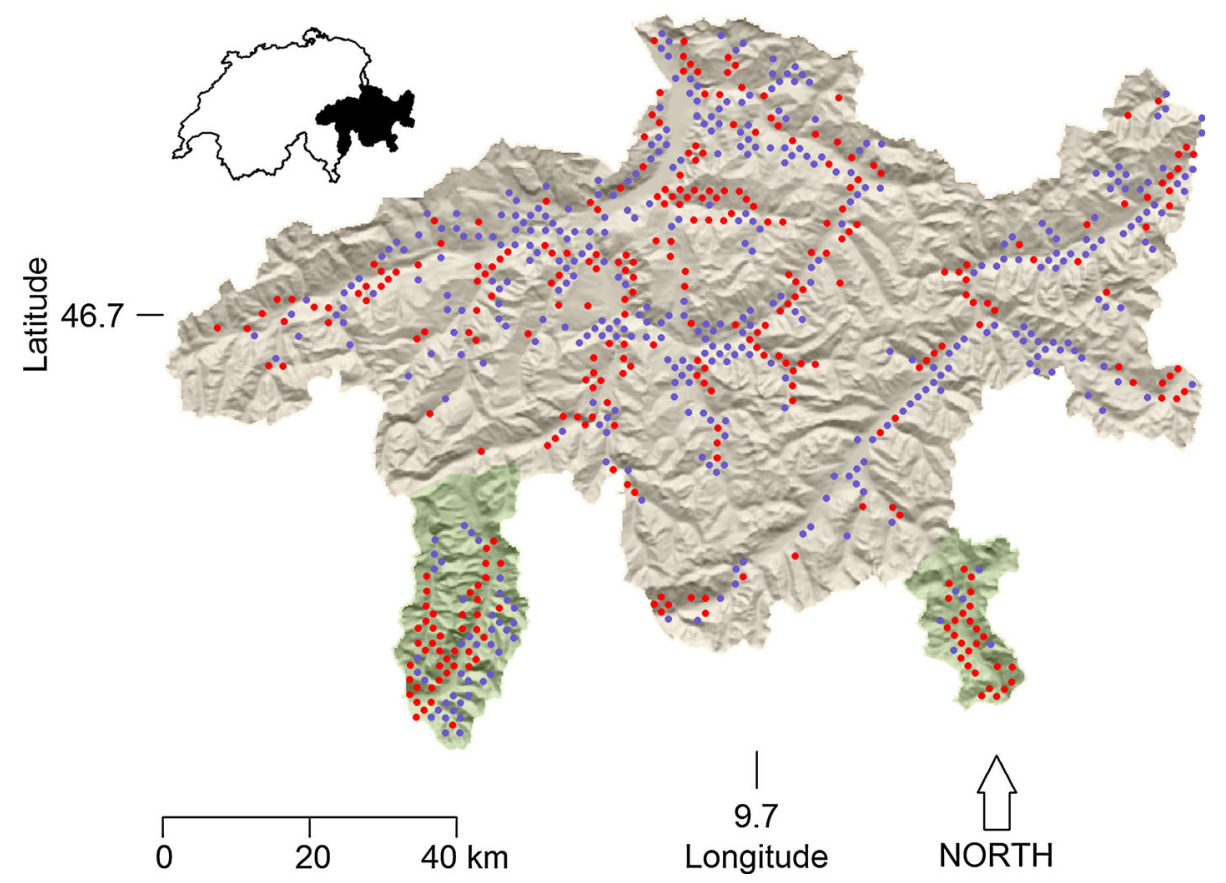


Table 1 NFI measurements for the Grisons by production regions Alps (Northern Grisons) and Southern Alps (Southern Grisons) and in- and outside the protection forest perimeter

\begin{tabular}{lllllll}
\hline Region & $\begin{array}{l}\text { Protection } \\
\text { forest }\end{array}$ & $\begin{array}{l}\text { No. of sample } \\
\text { plots }\end{array}$ & $\begin{array}{l}\text { Growing stock } \\
\left(\mathrm{m}^{3} \mathrm{ha}^{-1}\right)\end{array}$ & $\begin{array}{l}\text { Timber harvest } \\
\left(\mathrm{m}^{3} \mathrm{ha}^{-1} \mathrm{year}^{-1}\right)\end{array}$ & $\begin{array}{l}\text { Timber harvest }+\begin{array}{c}\text { Volume increment } \\
\text { mortality }\left(\mathrm{m}^{3} \mathrm{ha}^{-1} \mathrm{year}^{-1}\right)\end{array} \\
\left(\mathrm{m}^{3} \mathrm{ha}^{-1} \mathrm{year}^{-1}\right)\end{array}$ \\
\hline Northern Grisons & Inside & 234 & $319 \pm 13$ & $2.8 \pm 0.5$ & $3.0 \pm 0.5$ & $6.0 \pm 0.2$ \\
& Outside & 346 & $297 \pm 11$ & $2.4 \pm 0.4$ & $2.5 \pm 0.4$ & $5.7 \pm 0.2$ \\
& Total & 580 & $306 \pm 8$ & $2.5 \pm 0.3$ & $2.7 \pm 0.3$ & $5.8 \pm 0.2$ \\
Southern Grisons & Inside & 71 & $308 \pm 21$ & $0.2 \pm 0.1$ & $0.6 \pm 0.2$ & $5.7 \pm 0.4$ \\
& Outside & 47 & $280 \pm 24$ & $0.4 \pm 0.2$ & $0.5 \pm 0.2$ & $5.5 \pm 0.6$ \\
\multirow{5}{*}{ Total } & Total & 118 & $297 \pm 16$ & $0.3 \pm 0.1$ & $0.6 \pm 0.2$ & $5.6 \pm 0.3$ \\
& Inside & 305 & $317 \pm 11$ & $2.2 \pm 0.4$ & $2.4 \pm 0.4$ & $5.9 \pm 0.2$ \\
Grand total & Outside & 393 & $295 \pm 10$ & $2.1 \pm 0.3$ & $2.2 \pm 0.3$ & $5.7 \pm 0.2$ \\
\hline
\end{tabular}

Growing stock was observed at NFI3 and the yearly timber harvest, the timber harvest together with random and wind-induced mortality and volume increment refer to the NFI2-NFI3 period. All quantities and their standard error of means refer to wood measured over bark above ground from the base to the top of the stem without branches (stemwood)

\section{Model of forest development}

MASSIMO is a dynamic, stochastic individual tree model that was developed to simulate the development of tree populations on sample plots of the Swiss NFI. Empirical NFI-derived functions are used to simulate growth, removals due to forest management and mortality due to windthrow and self-thinning (density-dependent mortality) as well as regeneration of trees in ten-year time-steps (Kaufmann 2001a; Thürig et al. 2005a; Thürig and Kaufmann 2010).

The nonlinear growth function relates basal area increment (BAI) to tree diameter ( $\mathrm{dbh}$ ) and predictors of stand structure (basal area, basal area of trees larger than the focal tree, stand age, dominant diameter), site (site index, elevation above sea level) and management (growth release following management intervention). Thürig et al. (2005a) evaluated the growth function with independent data from Liechtenstein finding that MASSIMO simulations approximated basal area per hectare in Liechtenstein after 12 years of growth very precisely (underestimation of $0.65 \%$ ). We here provide a brief description of the model mainly focusing on the management module and refer to previous publications for more details of the other modules (Kaufmann 2001a, 2011; Thürig et al. 2005a; Thürig and Kaufmann 2010).

MASSIMO accounts for the removal of trees due to shelterwood felling and thinning and for density-dependent, storm-induced and random-caused mortality. Intervention criteria and removal intensities for shelterwood felling and thinning can be defined by the user (Table 2). For shelterwood felling, sample plots are prioritized by stand age with the number of treated plots being determined by rotation lengths $\left(R_{\text {shelt }}\right)$, which depend on site index and the share of conifers (Table 16 in Hofer et al.
2011). By default, thinning is simulated if stand basal area exceeds $110 \%$ of the basal area observed before the last thinning $\left(\mathrm{dBA}_{\text {thin }}\right)$. To simulate different management scenarios, rotation lengths $R_{\text {shelt }}$ and the default $110 \%$ for $\mathrm{dBA}_{\text {thin }}$ can be varied for individual decades and productions regions. Thus, $R_{\text {shelt }}$ and $\mathrm{dBA}_{\text {thin }}$ control the frequency of shelterwood felling and thinning, respectively, at the landscape scale by determining the time-interval between two successive interventions. In addition, the user can vary the intensity of these treatments, i.e., the percentage of stems and basal area that are removed with shelterwood felling and thinning, respectively. Given userdefined treatment intensities, the frequency parameters $R_{\text {shelt }}$ and $\mathrm{dBA}_{\text {thin }}$ can be adjusted to approximate scenariospecific targets. Results from a first simulation run with default $R_{\text {shelt }}$ and $\mathrm{dBA}_{\text {thin }}$ are compared to target values of either harvesting amounts or standing volume. In an iterative adjustment of $R_{\text {shelt }}$ and $\mathrm{dBA}_{\text {thin }}$, the difference between the simulation and the target value is minimized. To keep management interventions within a silviculturally plausible range, there is an upper limit in defining the thinning frequency. Stand basal area in the focal decade must be at least $90 \%$ of the basal area at the previous intervention. We ran five iterations to define $R_{\text {shelt }}$ and $\mathrm{dBA}_{\text {thin }}$ specific for each decade and production region.

Shelterwood cutting in MASSIMO approximates a shelterwood system that is comprised of seed cutting, one to two secondary cuttings and a final cutting that are conducted over a time period of 10-30 years (Burschel and Huss 1997). To account for the seed cutting (in Switzerland typically $30-50 \%$ of basal area) and a first secondary cutting, MASSIMO removes by default $80 \%$ of the trees $>12 \mathrm{~cm} \mathrm{dbh}$ on a sample plot in a first 10-year time step (decade). The remaining trees are removed in a final cutting in the subsequent decade in the colline to lower 
Table 2 Implementation of management strategies in MASSIMO for forests outside and within the protection forest perimeter

\begin{tabular}{|c|c|c|}
\hline No. & Outside protection forest perimeter ( $66 \%$ of sample plots) & Within protection forest perimeter ( $44 \%$ of sample plots) \\
\hline 1 & \multirow{2}{*}{\multicolumn{2}{|c|}{$\begin{array}{l}\text { No management (no mgmt) } \\
\text { No shelterwood felling and thinning except for salvage logging of storm-felled timber }\end{array}$}} \\
\hline & & \\
\hline \multirow[t]{6}{*}{2} & \multicolumn{2}{|l|}{ Business-as-usual (BAU, management as in NFI2-NFI3) } \\
\hline & \multicolumn{2}{|l|}{ Thinning: $30 \%$ of basal area removal } \\
\hline & \multirow{2}{*}{$\begin{array}{l}\text { Shelterwood felling: } 80 \% \text { of stems are removed in the first decade (seed and } \\
\text { first secondary cutting), removal of remaining trees within } 1 \text { or } 2 \\
\text { subsequent decades }\end{array}$} & Irregular shelterwood felling: \\
\hline & & $\begin{array}{l}\text { Stand age at start: colline-submontane belt } 120 \text { years, } \\
\text { montane belt } 140 \text { years and subalpine belt } 200 \text { years }\end{array}$ \\
\hline & \multirow[t]{2}{*}{$\begin{array}{l}R_{\text {shelt }} \text { and } \mathrm{dBA}_{\text {thin }} \text { were adjusted such that simulated timber harvests } \\
\text { approximate the NFI2-NFI3 observations }\end{array}$} & $\begin{array}{l}\text { Cutting cycle: colline-montane belt } 20 \text { years, subalpine } \\
\text { belt } 30 \text { years }\end{array}$ \\
\hline & & Removal: $40 \%$ of basal area \\
\hline
\end{tabular}

3, 6 Large treated area at lower intensity (large area). Variants: +50 and $+100 \%$ harvested timber as compared to BAU

Thinning: $25 \%$ of basal area removal

Shelterwood felling: $50 \%$ of stems are removed in the first decade (seed and Irregular shelterwood felling: first secondary cutting), removal of remaining trees within 1 or 2 subsequent decades

Stand age at start: colline-submontane belt 80 years; montane belt 100 years; subalpine belt 160 years

Cutting cycle and removal as in BAU

4, 7, Higher treatment intensity on a smaller area (intensive). Variants: $+50,+100$ and $+300 \%$ harvested timber as compared to BAU

9 Thinning: $40 \%$ of basal area removal

Shelterwood felling: $90 \%$ of stems are removed in the first decade (seed and Irregular shelterwood felling: final cutting), no secondary cuttings

Stand age at start as in large area scenario

Cutting cycle: colline-montane belt 30 years, subalpine belt 40 years

Removal: $50 \%$ of basal area

5, 8 Big trees first. Variants: +50 and $+100 \%$ harvested timber as compared to BAU

Thinning as in intensive scenario

Shelterwood felling:

Irregular shelterwood felling as in intensive scenario

Removal as in intensive scenario

First ranking criterion to prioritize sample plots for shelterwood felling is the occurrence of $\geq 2$ trees with $\mathrm{dbh}>50 \mathrm{~cm}$ per sample plot (40/ha).

Otherwise sample plots are prioritized by stand age as in BAU, large area and intensive scenarios

montane vegetation zones. A further secondary cutting and a final cutting are simulated within two subsequent decades in the upper montane to subalpine vegetation zones to account for slower growth of the regeneration at higher elevations.

Thinning removes by default $30 \%$ of the basal area at the sample plot level as observed between NFI2 and NFI3. The removal probability of individual trees during thinning depends on dbh and is modeled with a Weibull function (Kaufmann 2001a, b). Protection forests are not regenerated by shelterwood felling. Instead, we used MASSIMO's thinning routine to simulate an irregular shelterwood system that aims at a heterogeneous stand structure that combines a high tree (i.e., obstacle) density with a high individual tree resistance to disturbance and continuous forest renewal (Brang et al. 2006). Upon reaching a predefined stand age that depends on elevation (i.e., altitudinal zone), a series of high-intensity (default: $40 \%$ basal area removal) thinning interventions is simulated at a default interval of 20 years. Since MASSIMO is a non-spatial model, this implementation of an irregular shelterwood system cannot account for the size or shape of gap openings, but aims at approximating the timing of and intensity (percentage of removed basal area) of the felling. All removals of single trees are implemented stochastically by comparing the removal probabilities of shelterwood felling (e.g., 0.8 for the first decade) and thinning (as defined by the Weibull function) to uniform random draws. Windthrow was simulated as described by Thürig et al. (2005b). Storm occurrence and severity (percentage of windthrown trees) are simulated stochastically based on the observations of the past three largest storm events (1967, 1990, 1999; Pfister 1999), and storm-felled timber is assumed to be salvaged. The decadal probability of density-dependent 
mortality for single trees varies between 0 and 0.058 depending on stand basal area, conifer proportion and stand type (i.e., higher in late development stages). Random mortality occurs with a probability of 0.03 for each time step and accounts for pathogens, drought, fire and other agents that are not explicitly simulated. To account for these and the other stochastic model components, we replicated simulations 20 times.

Following shelterwood felling and windthrow, sample plots are re-populated (i.e., regenerated) with young trees $(1-12 \mathrm{~cm} \mathrm{dbh})$ based on the data from a randomly selected sample plot within the same production region and vegetation zone. In addition, MASSIMO accounts for regeneration that is independent form management and occurs throughout the simulations on all sample plots. When a young tree grows over the 12-cm dbh threshold, 8 new young trees of the same species are generated in sample plots in Northern Grisons and 10 in Southern Grisons, reflecting the more favorable growth conditions in Southern than in Northern Grisons. These new young trees are initialized with a dbh of $1 \mathrm{~cm}$ and survive a decade with a probability of 0.3. Regeneration in MASSIMO reflects the NFI2-NFI3 observations and does not respond to changes in environmental or stand structural conditions.

\section{Management scenarios}

To represent a wide array of timber mobilization alternatives, we developed 9 management scenarios in collaboration with representatives of the Office of Forest and Natural Hazards in the Canton of Grisons (Table 2). A nomanagement (no mgmt) and a business-as-usual (BAU) scenario served as baselines to show the relative importance of alternative mobilization scenarios. We defined 3 management strategies that we combined with varying targets of timber mobilization resulting in 7 alternative scenarios. All 7 scenarios differentiated management within and outside protection forests (Table 2).

- Large area This management strategy aimed at increasing the yearly treated area along with a decrease in treatment intensity given limited labor resources. This strategy was motivated by the public interest to combine timber mobilization with maximizing the area on which over-mature stands susceptible to disturbance are harvested.

- Intensive This strategy aimed at mobilizing timber most efficiently by increasing the intensity, i.e., removal percentage, per intervention while sacrificing treated area.

- Big trees first This strategy was motivated by interests of the timber industry and aimed at combining timber mobilization with a reduction in the growing stock of big trees, for the processing of which most sawmills are poorly equipped.

These three management strategies were implemented by varying the intensity (percentage of removal) of shelterwood felling and thinning (Table 2). This indirectly varied the frequency parameters of shelterwood felling and thinning $\left(R_{\text {shelt }}\right.$ and $\left.\mathrm{dBA}_{\text {thin }}\right)$ and therewith the treated area (number of sample plots) per decade because simulated timber harvests under each management strategy were tuned to the same regional target of harvested timber (see below). To harvest the same amount of timber (i.e., reach the same harvesting target) with a lower harvesting intensity, the harvesting frequency needs to be increased. That is, under the intensive strategy $R_{\text {shelt }}$ and $\mathrm{dBA}_{\text {thin }}$ are increased compared to the large area strategy, which results in longer cutting cycles, a smaller number of treated sample plots and thus a smaller treated area. We refer to Table 2 for more details on the implementation of the management strategies.

We ran all three management strategies with timber harvesting targets exceeding NFI2-NFI3 observations (i.e., BAU) by $50 \%$ and $100 \%$. Additionally, we ran the intensive strategy with an extreme harvesting target of $300 \%$ higher than BAU to explore the limits of timber mobilization. We applied the harvesting targets separately to Northern and Southern Grisons, initialized the scenario simulations with data from NFI3 (2006) and increased the harvesting target stepwise with no increase in the first decade 2007-2016, half the increase in the period 2017-2026 and a full increase from 2026 until the end of the simulations in year 2106 [Fig. S1 in the Electronic Supplementary Material (ESM)]. The harvesting targets were implemented by tuning $R_{\text {shelt }}$ and $\mathrm{dBA}_{\text {thin }}$ with the approximation routine described above. Sample plots in forest reserves and the Swiss National Park were excluded from any management intervention (GIS data by courtesy of Federal Office for the Environment 2015).

\section{Data analysis}

To quantify the effects of timber mobilization scenarios on forest development, we calculated growing stock $\left(\mathrm{m}^{3} \mathrm{ha}^{-1}\right)$, yearly timber harvest, wood increment and density-dependent mortality (all in $\mathrm{m}^{3} \mathrm{ha}^{-1}$ year $^{-1}$ ) based on the growth, removals and mortality of stem wood over bark as described by Kaufmann (2001b, 2011). We calculated cutting cycles as the average time period between two consecutive thinning and/or shelterwood felling interventions to depict and verify the expected differences between management strategies (short cycles in large area and long cycles in intensive scenarios). We classified sample plots with regard to basal area $\left(\mathrm{m}^{2} \mathrm{ha}^{-1}\right)$, quadratic 
mean diameter QMD $(\mathrm{cm})$ and stem number $\left(\right.$ stems ha ${ }^{-1}$ ) and used the frequency distribution of sample plots to assess scenario differences in landscape-scale forest structure. To evaluate the scenarios with respect to harvesting costs, we used the harvest and productivity model HeProMo (Frutig et al. 2015). This allowed us to allocate harvested timber volumes to three cost classes: $(0,80],(80$, 150], $>150$ Swiss Francs (CHF) per $\mathrm{m}^{3}$ based on plot-scale predictors of accessibility (e.g., slope, distance to road), survey data on the preferred extraction and harvesting method (e.g., cable yarding, mountain harvester, helicopter) and harvested assortments.

We stratified results to areas in- and outside the protection forest perimeter and Northern and Southern Grisons (Fig. 1) and used the double sampling procedure developed by the Swiss NFI to estimate standard error of means related to variation between sample plots and simulation replicates (Köhl 2001).

\section{Results}

\section{Growing stock}

Forest management had a strong impact on simulated forest development. Growing stock for the whole of the Grisons surpassed $>800 \mathrm{~m}^{3} \mathrm{ha}^{-1}$ by 2106 if management was completely ceased (Fig. 2). Under BAU growing stock development differed in- and outside protection forests. While in Northern Grisons it stabilized at $462 \pm 34 \mathrm{~m}^{3} \mathrm{ha}^{-1}$ in protection forests, it increased to $673 \pm 42 \mathrm{~m}^{3} \mathrm{ha}^{-1}$ by 2106 outside the protection forest perimeter with the increase accelerating in the second half of the simulation period. In Southern Grisons' protection forests, BAU management resulted in the growing stock to peak at $605 \pm 52 \mathrm{~m}^{3} \mathrm{ha}^{-1}$ in 2066 and then to decline to $532 \pm 66 \mathrm{~m}^{3} \mathrm{ha}^{-1}$ in 2106 . The growing stock outside the protection forest in Southern Grisons reached similar values $\left(769 \pm 82 \mathrm{~m}^{3} \mathrm{ha}^{-1}\right)$ as under the no-management scenarios.

The alternative timber mobilization scenarios resulted in varying developments of growing stock in- and outside protection forests and in Northern and Southern Grisons. In protection forests of Northern Grisons, all mobilization scenarios resulted in decreasing growing stocks. Starting from $319 \mathrm{~m}^{3} \mathrm{ha}^{-1}$ (Table 1) in 2006, growing stocks at the end of the simulations (2106) ranged from $281 \pm 25 \mathrm{~m}^{3} \mathrm{ha}^{-1}$ under the large area $+50 \%$ scenario to $215 \pm 20 \mathrm{~m}^{3} \mathrm{ha}^{-1}$ under the intensive $+100 \%$ scenario and $176 \pm 15 \mathrm{~m}^{3} \mathrm{ha}^{-1}$ under the intensive $+300 \%$ scenario. Outside protection forests, in contrast, none of the scenarios except for the extreme intensive $+300 \%$ scenario was able to bring growing stocks down. While under large area $+50 \%$ the growing stock increased to
$502 \pm 36 \mathrm{~m}^{3} \mathrm{ha}^{-1}$, it remained approximately at the 2006 (NFI3) level under the big trees first $+100 \%$ scenario $\left(351 \pm 32 \mathrm{~m}^{3} \mathrm{ha}^{-1}\right)$. The intensive $+300 \%$ scenario ended with $245 \pm 26 \mathrm{~m}^{3} \mathrm{ha}^{-1}$. While growing stock development in Southern Grisons varied only little between timber mobilization scenarios, it varied between forests in- and outside protection forests. In protection forests, unimodal growing stock development peaked between $477 \pm 52 \mathrm{~m}^{3} \mathrm{ha}^{-1} \quad$ (big trees first $+50 \%$ ) and $441 \pm 42 \mathrm{~m}^{3} \mathrm{ha}^{-1}$ (large area $+50 \%$ ) in the year 2056 and ended with values similar to those at simulation begin. Outside protection forests, even with a double $(+100 \%)$ and fourfold $(+300 \%)$ increase, the low regional timber harvests over the whole simulation period caused growing stock under the timber mobilization scenarios to follow a similar development as in the no-management scenario.

\section{Cutting cycles}

Cutting cycles differed between production regions, in- and outside the protection forest and timber mobilization scenarios. These differences emerged from the region- and scenario-specific parameterization of management (Table 2). Cutting cycles in Northern Grisons ranged from 17 to 42 years in protection forests and from 21 to 247 years outside protection forests (Fig. S4 in the ESM). The generally shorter cutting cycles in protection forests resulted from the irregular shelterwood felling that was implemented to simulate the maintenance of a predefined protective effect. The frequency of the irregular shelterwood felling was determined solely by stand age, independent of the management history and the scenariospecific harvesting targets that determined (via $R_{\text {shelt }}$ and $\left.\mathrm{dBA}_{\text {thin }}\right)$ the frequency of shelterwood felling and thinning outside the protection forest. Cutting cycles were generally longer in Southern Grisons, where outside protection forests the rare management interventions resulted in cutting cycles $>138$ years. Higher treatment intensity (intensive and big trees first vs. large area) leads to longer cutting cycles given the same harvesting target. Given the same management strategy (i.e., treatment intensity), an increase in the harvesting target (i.e., from +50 to +100 or $+300 \%$ ) leads to shorter cutting cycles. These results show that management scenarios had been simulated as anticipated.

\section{Timber harvest}

Simulated timber harvests in Northern Grisons generally approximated scenario-specific targets well (Fig. 2, Fig. S1 in the ESM), with some deviating fluctuations driven by forest age structure and the prioritized management in protection forests. In Northern Grisons' protection forests, harvests exceeded targets between 2026 and 2036 because 

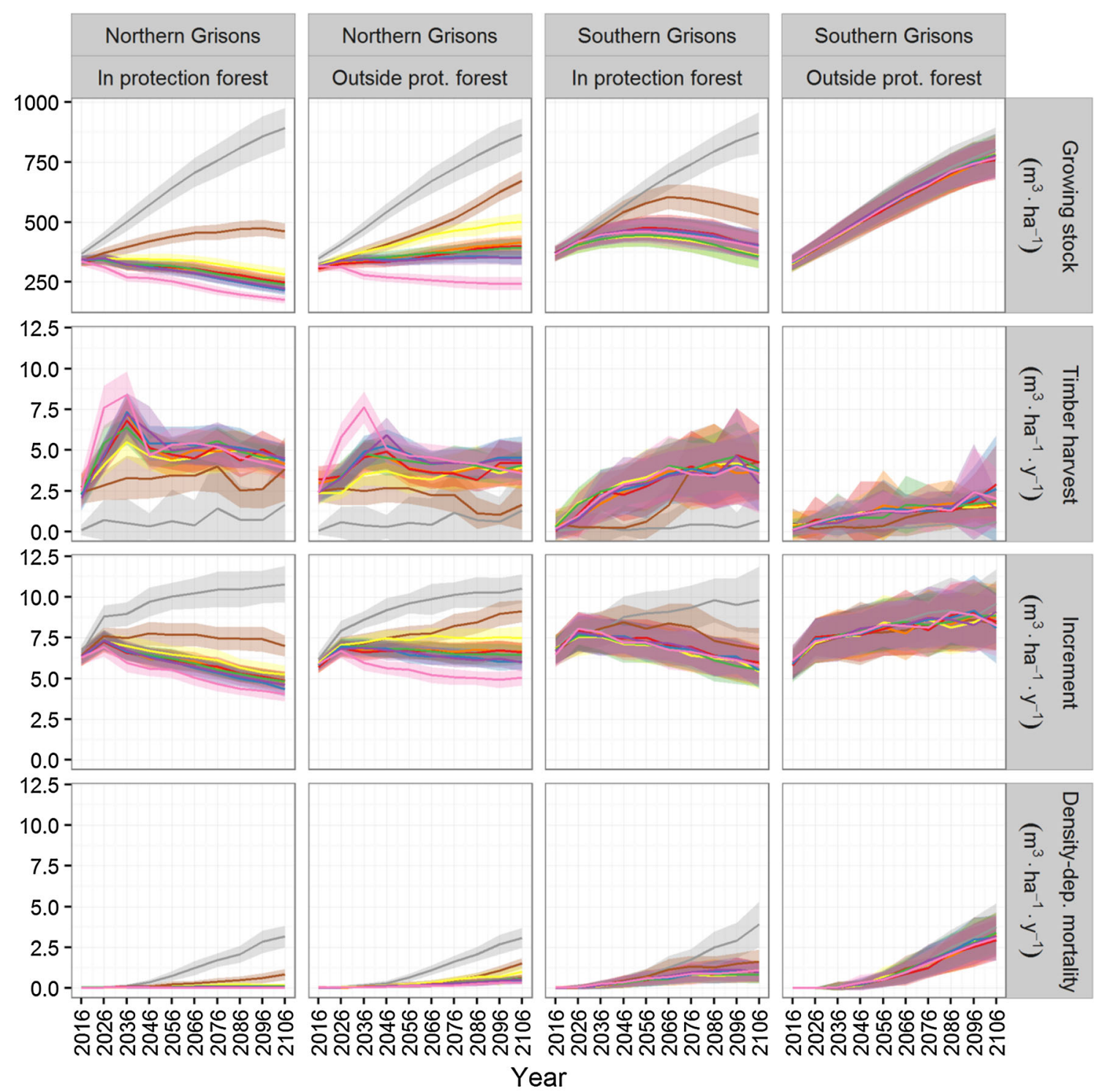

Year

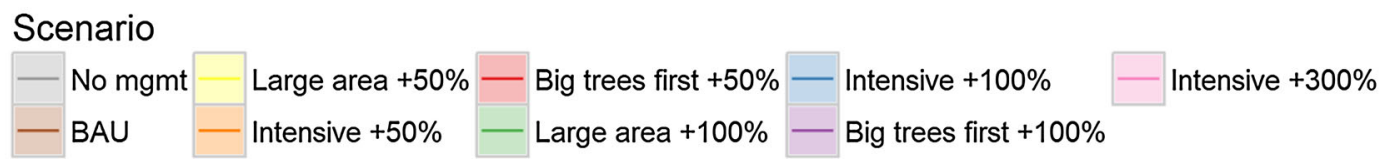

Fig. 2 Development of growing stock, harvested timber, volume increment and density-dependent mortality from 2016 to 2106 in two regions and in- and outside protection forests. Error bands indicate variation between sample plots and simulation replicates as standard errors of means. (Color figure online)

many sample plots reached the 160-year threshold triggering irregular shelterwood felling (note the peak in stand age distribution between 100 and 150 years in Fig. S5 in the ESM, Table 2). Because harvesting goals were defined for entire production regions spanning forests in- and outside the protection forest perimeter, the increase in harvest in protection forests was compensated with reduced thinning and shelterwood felling outside protection forests (Fig. S4 in ESM). This in turn caused the diverging growing stock developments in- and outside protection forests.
Other developments in timber harvests driven by forest age structure included a sharp decline in timber harvest in 2036 under the intensive $+300 \%$ scenario. After 2036, the application of only age-dependent irregular shelterwood felling in protection forests, which could not be adjusted with $R_{\text {shelt }}$ and $\mathrm{dBA}_{\text {thin }}$, the $90 \%$ restriction for $\mathrm{dBA}_{\text {thin }}$ and the scarcity of large trees (Fig. 3) limited harvests to amounts similar to those simulated for the other mobilization scenarios. Stand age is more evenly distributed in protection forests in Southern Grisons than in Northern 
Fig. 3 Forest structure displayed as the proportion of sample plots in classes of quadratic mean diameter (QMD) in 2006 (NFI3 observation, '06) and years 2056 and 2106 under simulated management scenarios and for two regions and in- and outside protection forests. (Color figure online)

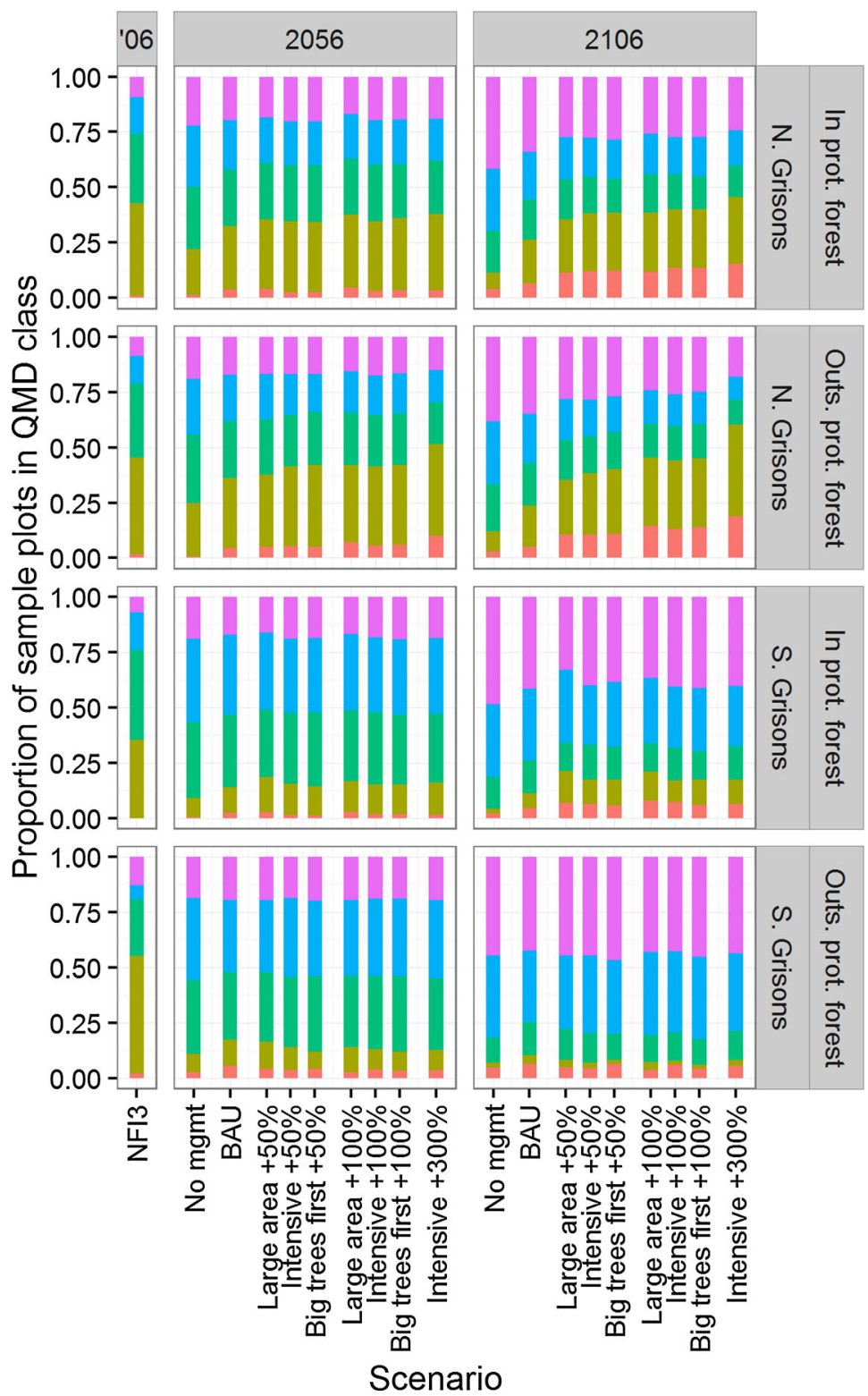

Quadratic mean diameter $(\mathrm{cm})$

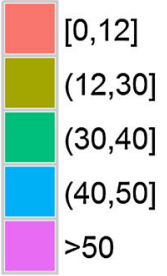
$(12,30]$ $(30,40]$ $(40,50]$ $>50$
Grisons (Fig. S5 in the ESM) which resulted in a more gradual harvest increase in Southern than in Northern Grison. Timber harvest in Southern Grison's protections forests exceeded targets due to un-adjustable irregular shelterwood felling. Outside protection forests, management in Southern Grisons was restricted to salvage logging after windthrow, which is the only contribution to timber harvests also under the no-management scenario.

\section{Increment}

Increment decreased with decreasing growing stock under timber mobilization strategies (see also Fig. S2 in the ESM). Consequently, timber mobilization by means of reducing growing stock negatively affects forest productivity and thus future timber harvests. Increment developments show a consistent sharp increase in the second simulation decade (Fig. 2). This is a model artifact that is subject to ongoing investigations. Because the species-specific survival rates for young trees used in the regeneration model were estimated for the whole of Switzerland, they presumably cause an overestimation of ingrowth and thus increment in the Grisons. While this hampers the interpretation of absolute increment values, it does not affect the interpretation of the relative differences between scenarios and the long-term trends (Temperli et al. 2013b).

\section{Density-dependent mortality}

Density-dependent mortality generally increased over time and with increasing growing stock (Fig. 2, Fig. S3 in the 
ESM). Hence, it was highest under the no-management scenario and lowest under scenarios with high harvesting targets (e.g., the intensive $+300 \%$ scenarios). Outside the protection forest in Southern Grisons, the development of density-dependent mortality was similar under all scenarios as were developments in timber harvesting and growing stock. Unlike the annual increments that approximate an upper limit at high growing stocks, density-dependent mortality generally increased exponentially with increasing growing stock. Interestingly, density-dependent mortality continued to increase slightly as growing stock started to decrease in 2056 in Southern Grisons' protection forests (Fig. 2, also see the croissant-shaped patterns in Fig. S3 in the ESM). This can be explained by a shift in landscapescale forest structure. Protection forests in Southern Grisons became increasingly heterogeneous, with the proportion of sample plots in quadratic mean diameter (QMD) classes $>40 \mathrm{~cm}$ (Fig. 3) and basal area $>60 \mathrm{~m}^{2} \mathrm{ha}^{-1}$ (Fig. S6 in the ESM) increasing under all scenarios. Density-dependent mortality in MASSIMO is modeled, inter alia, as a function of basal area. Thus, a larger proportion of forest area in high basal area and QMD classes may lead to increased density-dependent mortality even though growing stock aggregated at the level of protection forests in Southern Grisons decreases.

\section{Forest structure}

The harvesting target was more important in driving forest structure than the management strategy (Fig. 3). While distributions of sample plots in QMD classes were similar between management strategies (large area, intensive and big trees first), slightly more sample plots were in the smaller size classes in scenarios with higher harvesting targets. In 2106, QMD in Northern Grisons and outside protection forests was in $24 \%$ of sample plots $<30 \mathrm{~cm}$ if BAU management continued. Under the large area $+100 \%$ scenario, this proportion was $45 \%$. The effect of increased timber harvest was most pronounced in Northern Grisons outside the protection forest perimeter. In protection forests, the effect of the harvesting target was smaller because the simulation of irregular shelterwood felling depended on stand age and not on the harvesting target. Under all timber mobilization scenarios, forest structure in Southern Grisons remained similar to the simulations under BAU. Assessing forest structure with sample plot distributions in basal area and stand density classes revealed similar patterns (Fig. S6 and $\mathrm{S} 7$ in the ESM).

\section{Harvesting costs}

Harvesting costs tended to be higher in scenarios with higher timber harvesting targets (Fig. 4). While in protection forest in Northern Grisons 30\% of the timber volume was harvested at costs $>150 \mathrm{CHF}$ under BAU, under the intensive $+100 \%$ scenario the costs of $35 \%$ of the harvested volume exceeded $150 \mathrm{CHF}$. This trend was less pronounced outside protection forests. The projected harvesting costs in Southern Grisons' protection forests (33\% in $>150 \mathrm{CHF}$ class under BAU) were generally higher than in the protection forest in Northern Grisons ( $30 \%$ in $>150 \mathrm{CHF}$ class under BAU). In Southern Grisons' protection forest, the proportion of harvested volume in the $>150 \mathrm{CHF}$ cost class was higher under the timber mobilization scenarios than under BAU. Outside the protection forest, however, no trend can be identified due to low harvesting amounts and the lack of survey data (see Fig. 4 caption).

\section{Discussion}

By combining inventory-based forest growth modeling and expert-based scenario development, we projected the development of mountain forests in the Swiss canton of Grisons under nine timber mobilization scenarios. These simulations provide new insights into the interactions between timber mobilization and regulations and incentives for protection forest management for a region that represents a broad range of environmental and socioeconomic conditions and is typical for Central European mountain forests. In the following, we discuss our results with respect to the three questions asked in the introduction, address the limitations of our approach and conclude by identifying consequences for mountain forest management and further research directions.

\section{Effect of timber mobilization scenarios on growing stock and increment}

The strong reduction in growing stock with increased protection forest management in the Northern Grisons and the concomitant divergence of forest development in- and outside the protection forest perimeter may seem counterintuitive. Often, strong government interventions in protection forest management are perceived as a restriction to timber mobilization because regeneration in protection forests needs to be initialized with multiple interventions over several decades (Brang et al. 2006; Frehner et al. 2005). Nevertheless, protection forest management acted as a strong driver of timber mobilization in our projections, such that simulated harvests in protection forests exceeded those outside the protection forest perimeter on a per ha basis. Consequently, the increased timber supply from protection forest management diminished the need for harvesting outside protection forests, given a fixed regional 
Fig. 4 Proportion of harvested volumes in classes of harvesting costs. Proportions were calculated for timber volumes harvested over the whole simulation period. NA means that sample plots lacked survey data to allocate a harvesting cost class. (Color figure online)

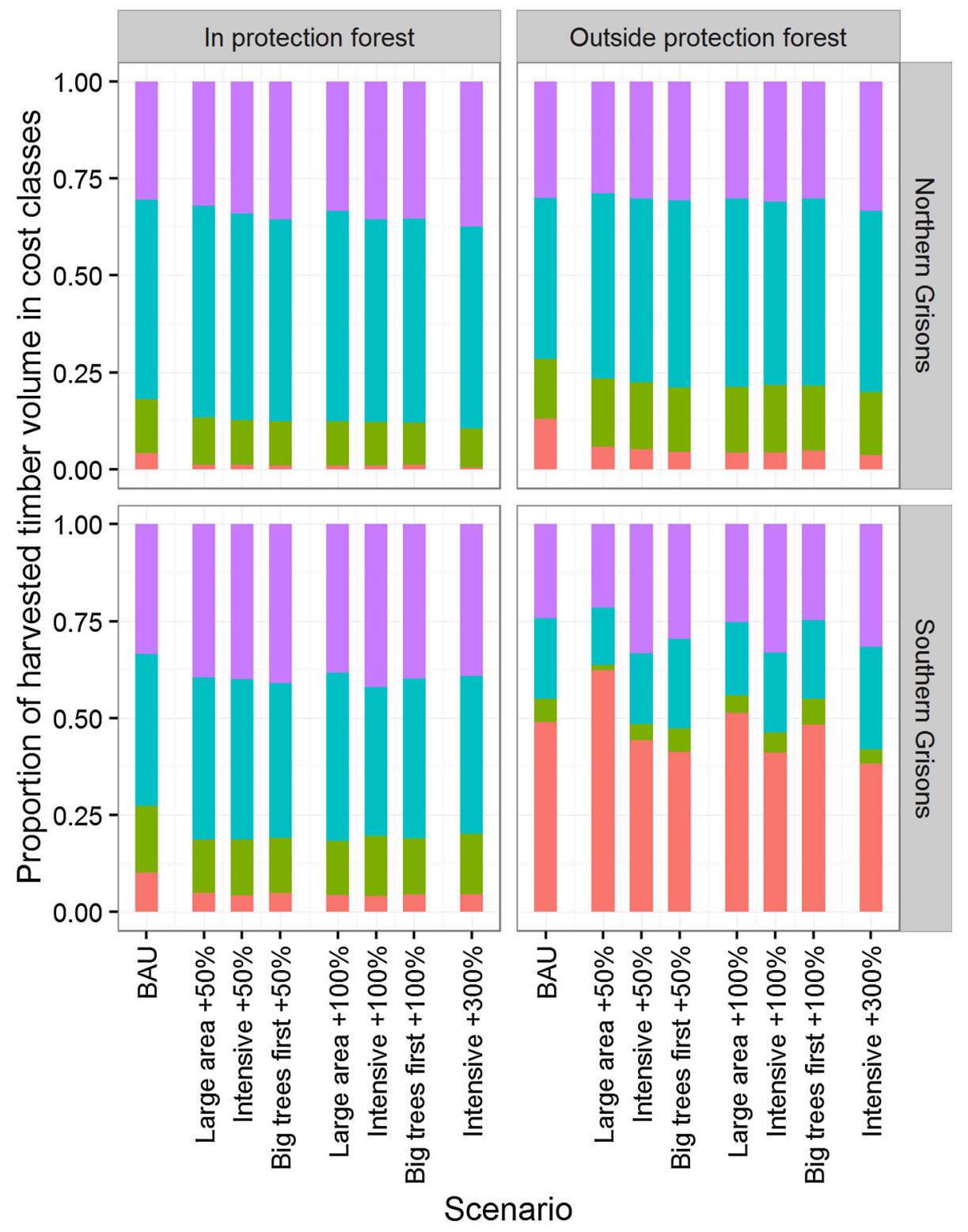

Harvesting costs (CHF) $\square$ NA $\square(0,80] \square(80,150] \square>150$ target for timber harvesting as in our scenarios. Thus, this study is the first to quantitatively display the potential landscape-scale effects of incentives for and regulations of protection forest management under varying scenarios of timber mobilization targets. It complements both previous NFI-based simulation studies that did not differentiate between forests in- and outside the protection forest perimeter (Stadelmann et al. 2015, 2016), and stand-scale, process-based simulation approaches that assumed harvests to completely utilize the increment (Rasche et al. 2013; Schmid et al. 2015; but cf. Maroschek et al. 2014).

The growing stock reduction that we projected for protection forests in Northern Grisons may be too extreme in the long term. By 2106 basal area in 44-53\% (large area + $50 \%$ - intensive $+100 \%$ ) of the sample plots in these forests dropped below $20 \mathrm{~m}^{2} \mathrm{ha}^{-1}$, which is considered as a rough lower limit for protection against rockfall (Dorren et al. 2015). However, forests patches in young development phases with low growing stock and small basal area are more resistant to disturbances and resilient to risk due to climate change and thus contribute to long-term forest stability and protection against gravitational hazards (DeRose and Long 2014; Seidl et al. 2011a). Previous modeling studies also found reductions in the protection effect following thinning. Schmid et al. (2015) projected small short-term reduction in the protection against 
avalanches for subalpine forest across Switzerland following simulated group selection thinning and Bigot et al. (2008) found an almost twofold increase in rock fall hazard following thinning with $50 \%$ stem density reduction in the French Alps. Thus, short-term reductions in the protection effect at the level of forest patches in response to management interventions need to be accepted to maintain the long-term protective effect at the landscape scale.

While in protection forests no compromises can be made regarding the protection effect, there may be situations outside the protection forest, where mature forest stands can be retained to allow for deadwood accumulation and the development of microhabitats that benefit biodiversity (Lassauce et al. 2011). However, blowdown in unmanaged, over-mature stands may trigger bark beetle calamities that are difficult to control and may spill over to critical stands within protection forest perimeters (Brůna et al. 2013; Kautz et al. 2011; Økland et al. 2016) as currently observed around forest reserves in the Grisons (Bühler, pers. communication).

The simulated reduction in growing stock in Northern Grisons' protection forests reduced yearly volume increments from $6.0 \mathrm{~m}^{3} \mathrm{ha}^{-1}$ year $^{-1}$ between NFI2 and NFI3 to 5.2 (large area $+50 \%$ ) and $4.3 \mathrm{~m}^{3} \mathrm{ha}^{-1}$ year $^{-1}$ (intensive $+100 \%$ ) between 2096 and 2106 (Fig. 2, Fig. S2 in the ESM). This drop in increment under the timber mobilization scenarios is due to the reduction in large diameter trees (see also Fig. 3) and contrasts with the BAU scenario, where increment remained approximately constant. Basal area increment (i.e., tree growth) is in MASSIMO positively (and sigmoidally) related to tree diameter (Thürig et al. 2005a). Therefore, it is not surprising that this and also previous MASSIMO applications found growth declines in response to increased harvesting and growing stock reduction (Hofer et al. 2011; Stadelmann et al. 2016). Growth declines reduce future timber harvests such that forest management must consider timber mobilization and protective effects both now and in future decades (Cordonnier et al. 2008).

\section{Effect of management strategies on forest structure}

The response of forest structure to differences in management strategies was small. While the differences in thinning intensity between strategies were reflected by cutting cycle lengths (Fig. S4 in the ESM), they did not lead to an expected more even distribution of QMD, basal area and stem density under the large area than under intensive and big tree first strategy. A similar insensitivity of simulated mountain forest development to varying management strategies (plentering vs. age-class forestry) has also been found by Rasche et al. (2013). In our case, forest structure did not respond because the effect of the treated area (i.e., number sample plots) was canceled out by the lower thinning intensity. That is, increasing the number of treated sample plots as under the large area strategy and increasing the thinning intensity as under the intensive and the big trees first strategy had a similar effect on the probability of a sample plot to fall into a small QMD, basal area and stem density class. The intensive and big trees first strategy led to similar results because big trees tended to be in sample plots with high stand age (Fig. S5 in the ESM) leading to a similar prioritization for shelterwood cutting for both strategies.

For a more detailed assessment of forest structural dynamics in response to varying thinning and regeneration strategies, a stand-scale focus that accounts for positions of individual trees may be more revealing with respect to protection forest management than the distance-independent modeling approach we employed in this study. Observational and experimental studies on regeneration in thinned mountain forest stands (Baier et al. 2005; Streit et al. 2009) are crucial as a basis for long-term scenario analyses. Dynamic forest models that depict regeneration processes in response to stand structural and environmental conditions are particularly suited for such analyses (Brauner et al. 2005; Wehrli et al. 2006a, b). While stand-scale model analyses are restricted to small case studies, their application along environmental gradients may yield important insight at a landscape scale. To inform protection forest management, such model applications should focus on forest successional pathways in response to varying regeneration methods, ungulate browsing, climate change and their interactions (Didion et al. 2009, 2011; Rammer et al. 2015).

\section{Harvesting costs}

Harvesting costs per volume increased with increasing timber harvest in our simulations. This general trend implies that higher timber mobilization requires tapping timber resources at steep, remote, less accessible and thus cost-intensive stands (Frutig et al. 2015). Poor accessibility and thus cost-intensive extraction methods (e.g., helicopter yarding) are also the reasons for the generally higher harvesting costs in Southern Grisons. In Southern Grisons, a large part (49\% under BAU) of the harvested volume could not be allocated to any cost class because the local foresters, which were interviewed during the forest inventory, were unable to indicate the preferred extraction method for plots on which no recent intervention took place. Because these sample plots are mostly located on poorly accessible and on steep slopes, the unclassified timber volume can most likely be allocated to a high (e.g., $>150$ CHF) cost class. Against our expectations, the simulations did not show higher harvesting costs under the large area strategy 
than under the intensive strategy. We explain this result with the higher number of trees that are harvested per intervention under the intensive than under the large area strategy. This led to higher costs per intervention (Frutig et al. 2015), which in sum canceled out the reduced costs due to the lower amount of interventions per year. Further investigations are necessary to quantify this effect.

Current market prices for various spruce round wood assortments in the Grisons range from CHF 61 to 92 per $\mathrm{m}^{3}$ (Selva 2016). With these timber revenues and the costs of most of our simulated harvest being $>80 \mathrm{CHF} / \mathrm{m}^{3}$, timber harvesting in Grisons needs to be subsidized (see also Stadelmann et al. 2015, 2016). While the mobilization of large diameter timber may at least in the short term bring more revenue (Erni and Frutig 2005), marketing these large diameter assortments is difficult because they cannot be processed by many sawmills in the Grisons (Bürgi et al. 2010). The generally high costs for labor and machinery allocated to relatively small forest management areas also contribute to the high harvesting costs in Switzerland (Bürgi and Pauli 2013). In Austria, rationalization of harvesting could substantially reduce harvesting costs as reduced round wood prices dropped in the past decades (Foglar-Deinhardstein et al. 2015, pp. 106-107). Hence, Rammer et al. (2015) were able to show that in Austria a high level of rockfall protection can be maintained in the long term at acceptable costs by enhancing continuous regeneration with slit shaped gaps (Streit et al. 2009).

\section{Limitations}

Our projections represent possible trajectories of forest development, given NFI observations that determine tree growth, mortality and regeneration and given management scenarios that we defined together with representatives of Grisons' Office of Forest and Natural Hazards. As such, our projections are afflicted with uncertainties from several sources. First, the projections are based on a sample of the forests in Grisons (the NFI sample plots) that is subject to sampling error. Second, MASSIMO represents several processes stochastically (e.g., tree mortality and storm), which causes variation between replicate simulation runs. We quantified the standard errors that are related to these two sources of uncertainty for growing stock, volume increment, etc. by stratum (Fig. 2). However, we could not account for uncertainties related to model parameters (i.e., growth and volume estimation models), environmental drivers (e.g., plot-specific site index and topography) and, most importantly, the implementation and parameterization (i.e., scenarios) of forest management. For example, our assumption on fixed harvesting targets (i.e., $+50,+100$ and $+300 \%$ with respect to NFI2-NFI3 levels) until 2106 may not be realistic. These fixed harvesting targets were deliberately chosen high and potentially over-optimistic. Rather than to reflect a realistic future, we intended to embrace the harvesting level required to stabilize growing stock and to reveal responses of the system that would have been masked at low harvesting levels, i.e., the developments in forest structure and harvesting costs.

Under the intensive $+300 \%$ scenarios and outside protection forests in Southern Grisons, we projected developments toward high growing stocks. While Maroschek et al. (2014) simulated similar growing stock increases under a no-management scenario in the Austrian Eastern Alps, the low number of NFI sample plots representing these high growing stocks may raise concerns on the applicability of the functions for growth and density-dependent mortality in MASSIMO for these situations. These functions may miss some of the competition effect that occurs at high growing stock (Castagneri et al. 2008; Krumm et al. 2012). This in turn may have led to an overestimation of the projected increment and an underestimation of density-dependent mortality at high growing stock, an assumption that needs further testing.

Our projections are not sensitive to climate variability. Hence, they do not account for shifts in species composition, forest productivity and disturbance dynamics in response to climate change. Dendroecological, inventorybased and modeling studies suggest increased productivity under scenarios of a warming climate in currently coldlimited mountain and high-latitude forests (Kapeller et al. 2012; Primicia et al. 2015; Reyer et al. 2014; Rohner et al. 2016). This implies that our simulation results may have underestimated future increment. Projected temperature increases may accelerate the development of bark beetle generations and likely the risk of future outbreaks (Stadelmann et al. 2014; Temperli et al. 2013a; Wermelinger and Schneider Mathis 2014). Drought-induced growth reductions, mortality and associated wild fire risk will likely increase under climate change at lower elevations and at xeric sites in the Alps (Bigler et al. 2006; Eastaugh and Hasenauer 2014; Lévesque et al. 2013; Rigling et al. 2014; Wastl et al. 2012). Yet, most forests in the Grisons grow under more mesic conditions at high elevations where drought currently plays minor role (Rigling et al. 2014; Vanoni et al. 2016) and, as projections show, will also under future climate change be of minor importance (Rasche et al. 2013; Schmid et al. 2015; Seidl et al. 2011b). Such disturbances will at least locally lead to abrupt growing stock reductions that we could not account for in our simulations. This, in turn, may create regeneration opportunities for broadleaves such as beech (Fagus sylvativa L.) and oaks (Quercus spp.) at elevations where currently conifers prevail (Thom et al. 2017). However, it is difficult to project whether or not disturbance-related increases in mortality rates may exceed the positive effect 
of temperature on increment at the landscape scale (Etzold et al. 2014; Maroschek et al. 2014; Reyer et al. 2017). In the light of these uncertainties, our projections should be interpreted with care, with the assumptions inherent to our modeling framework in mind and as answers to the whatif-questions that we asked with our scenarios.

\section{Conclusions}

Based on 698 National forest inventory plots, our projections show that with a continuation of current harvesting levels (i.e., business-as-usual) growing stocks in the Canton of Grisons, Switzerland, will further increase, and even more than double over the next 90 years in the most remote, southern parts of the Canton. This growing stock development increases the risk of insect, storm and in dry inner-Alpine valleys also fire disturbance, particularly as the temperature and the frequency and severity of drought are projected to increase with climate change. To stabilize growing stocks at current levels requires more than a doubling of current timber harvests. Our simulations of timber mobilization scenarios showed that governmental regulations and incentives for management in protection forests act as important drivers of timber mobilization in Grisons mountain forests. However, with financial compensations being primarily available for the management of protection forests, stands outside the protection forest perimeter are still at risk of over-maturity and disturbanceinduced mortality, even if $>50 \%$ increases in timber harvests were assumed.

We found harvesting costs to increase under the scenarios of increased timber mobilization. This means that even less management activities in Grisons' mountain forests could be covered by the revenues from the harvested wood than today. Thus, increased timber mobilization or even a stabilization of growing stocks can only be realized with financial compensations for forest ecosystem services other than timber provision. Subsidies for the promotion of protection forest management may yet leverage timber mobilization to some extent, but to stabilize growing stocks at the landscape level (i.e., Canton of Grisons), financial compensations would also have to be available for management interventions outside protection forests. These may include promoting advanced regeneration in particularly critical stands to increase their disturbance resistance and resilience and to prevent spillover of bark beetle or pathogen outbreaks to protection forests. Mobilizing timber at the level that we considered in our scenarios (i.e., +50 and $+100 \%$ of current harvests) would require substantial structural changes to the forest sector including investments in downstream wood processing facilities to cope with the higher timber supply.
Further research should focus on identifying the stand structural and environmental conditions that support advanced regeneration. This may stimulate the development of targeted and cost-effective thinning schemes and indicators of forest resilience. Measureable criteria and ecosystem service indicators that are based on NFI data need to be developed, agreed upon by the relevant stakeholders and integrated within the MASSIMO framework. This will allow the development of optimized management scenarios that balance timber mobilization goals, the forests' instantaneous and long-term protective effect, resistance and resilience to disturbance and other ecosystem services at a regional or even national scale.

Acknowledgements We thank Riet Gordon, Office of Forest and Natural Hazards of the Canton of Grisons, for his guidance during the development of management scenarios and critical assessments of simulation results. This research was funded by the Swiss National Science Foundation's 66th National Research Program (Grant No. 4066-40_136711).

\section{References}

Abegg M, Brändli U-B, Cioldi F (2014) Fourth national forest inventory-result tables and maps on the Internet for the NFI 2009-2013 (NFI4b). www.lfi.ch 28 Oct 2015

Baier R, Meyer J, Göttlein A (2005) Regeneration niches of Norway spruce (Picea abies [L.] Karst.) saplings in small canopy gaps in mixed mountain forests of the Bavarian Limestone Alps. Eur J For Res 126:11-22. doi:10.1007/s10342-005-0091-5

Barreiro S, Schelhaas M-J, Kändler G et al (2016) Overview of methods and tools for evaluating future woody biomass availability in European countries. Ann For Sci. doi:10.1007/s13595016-0564-3

Bebi P, Kulakowski D, Rixen C (2009) Snow avalanche disturbances in forest ecosystems - state of research and implications for management. For Ecol Manag 257:1883-1892. doi:10.1016/j. foreco.2009.01.050

Bigler C, Braker OU, Bugmann H et al (2006) Drought as an inciting mortality factor in Scots pine stands of the Valais, Switzerland. Ecosystems 9:330-343. doi:10.1007/s10021-005-0126-2

Bigot C, Dorren LKA, Berger F (2008) Quantifying the protective function of a forest against rockfall for past, present and future scenarios using two modelling approaches. Nat Hazards 49:99-111. doi:10.1007/s11069-008-9280-0

Brändli U-B (2010) Schweizerisches Landesforstinventar. Ergebnisse der dritten Erhebung 2004-2006. Eidgenössische Forschungsanstalt für Wald, Schnee und Landschaft WSL; Bundesamt für Umwelt, BAFU, Birmensdorf, Bern

Brang P, Schönenberger W, Bachofen H et al (2004) Schutzwalddynamik unter Störungen und Eingriffen: Auf dem Weg zu einer systemischen Sicht. Eidg Forschungsanstalt WSL Forum Für Wissen 55-66

Brang P, Schönenberger W, Frehner M et al (2006) Management of protection forests in the European Alps: an overview. For Snow Landsc Res 80:23-44

Brauner M, Weinmeister W, Agner P et al (2005) Forest management decision support for evaluating forest protection effects against rockfall. For Ecol Manag 207:75-85. doi:10.1016/j.foreco.2004. 10.018 
Brůna J, Wild J, Svoboda M et al (2013) Impacts and underlying factors of landscape-scale, historical disturbance of mountain forest identified using archival documents. For Ecol Manag 305:294-306. doi:10.1016/j.foreco.2013.06.017

Bürgi P, Pauli B (2013) Ansätze zur Senkung der Holzerntekosten in der Schweiz. Schweiz Z Forstwes 164:148-157. doi:10.3188/szf. 2013.0148

Bürgi P, Pauli B, Peter L et al (2010) Rundholzmarkt Graubünden. Handlungsempfehlungen zur Erhöhung des Angebots von sägefähigem Rundholz im Kanton Graubünden. 227

Burschel P, Huss J (1997) Grundriss des Waldbaus: ein Leitfaden für Studium und Praxis, 2nd ed. Parey

Camin P, Cioldi F, Röösli B (2015) Growing stock. Forest report 2015 condition and use Swiss forest. Swiss Federal Office for the Environment FOEN, Bern, and Swiss Federal Institute for Forest, Snow and Landscape Reseach WSL, Birmensdorf, pp 32-33

Castagneri D, Vacchiano G, Lingua E, Motta R (2008) Analysis of intraspecific competition in two subalpine Norway spruce (Picea abies (L.) Karst.) stands in Paneveggio (Trento, Italy). For Ecol Manag 255:651-659. doi:10.1016/j.foreco.2007.09.041

Cordonnier T, Courbaud B, Berger F, Franc A (2008) Permanence of resilience and protection efficiency in mountain Norway spruce forest stands: a simulation study. For Ecol Manag 256:347-354. doi:10.1016/j.foreco.2008.04.028

DeRose RJ, Long JN (2014) Resistance and resilience: a conceptual framework for silviculture. For Sci 60:1205-1212

Didion M, Kupferschmid AD, Bugmann H (2009) Long-term effects of ungulate browsing on forest composition and structure. For Ecol Manag 258:S44-S55

Didion M, Kupferschmid A, Wolf A, Bugmann H (2011) Ungulate herbivory modifies the effects of climate change on mountain forests. Clim Change 109:647-669. doi:10.1007/s10584-0110054-4

Dodoo A, Gustavsson L, Sathre R (2012) Effect of thermal mass on life cycle primary energy balances of a concrete- and a woodframe building. Appl Energy 92:462-472. doi:10.1016/j.ape nergy.2011.11.017

Dorren LKA, Berger F, le Hir C et al (2005) Mechanisms, effects and management implications of rockfall in forests. For Ecol Manag 215:183-195. doi:10.1016/j.foreco.2005.05.012

Dorren L, Berger F, Frehner M et al (2015) Das neue NaiSAnforderungsprofil Steinschlag. Schweiz Z Forstwes 166:16-23. doi:10.3188/szf.2015.0016

Eastaugh CS, Hasenauer H (2014) Deriving forest fire ignition risk with biogeochemical process modelling. Environ Model Softw 55:132-142. doi:10.1016/j.envsoft.2014.01.018

Ellenberg H (1996) Vegetation Mitteleuropas mit den Alpen in ökologischer, dynamischer und historischer Sicht. Ulmer, Stuttgart

Erni V, Frutig F (2005) Vorkalkulation in der voll mechanisierten Holzernte. Wald Holz 1:55-57

Etzold S, Waldner P, Thimonier A et al (2014) Tree growth in Swiss forests between 1995 and 2010 in relation to climate and stand conditions: Recent disturbances matter. For Ecol Manag 311:41-55. doi:10.1016/j.foreco.2013.05.040

Federal Office for the Environment (2013) Waldpolitik 2020. Visionen, Ziele und Massnahmen für eine nachhaltige Bewirtschaftung des Schweizer Waldes. Bundesamt für Umwelt, Bern

Ferranti F (2014) Energy wood: a challenge for European forests. Potentials, environmental implications, policy integration and related conflicts. EFI technical report 95, European Forest Institute

Fischer C, Camin P (2015) Timber use and increment. Forest report 2015 condition and use Swiss forest. Swiss Federal Office for the Environment FOEN, Bern, and Swiss Federal Institute for
Forest, Snow and Landscape Reseach WSL, Birmensdorf, pp 60-61

Foglar-Deinhardstein A, Piribauer V-C, Prem J (2015) Nachhaltige Waldwirtschaft in Österreich. Österreichischer Waldbericht 2015. Republik Österreich, Bundesministerium für Land- und Forstwirtschaft, Umwelt und Wasserwirtschaft, Wien

Forest Europe, UNECE, FAO (2011) State of Europe's forests 2011. Status and trends in sustainable forest management in Europe. In: Ministerial conference on the protection of forests in Europe, Oslo

Frehner M, Wasser B, Schwitter R (2005) Nachhaltigkeit und Erfolgskontrolle im Schutzwald. Wegleitung für Pflegemassnahmen in Wäldern mit Schutzfuntion. Bundesamt für Umwelt, Wald und Landschaft (BUWAL)

Frutig F, Holm S, Lemm R et al (2015) Kalkulation von Holzerntearbeiten: Das Produktivitätsmodell HeProMo. www.waldwis sen.net

Hofer P, Altwegg J, Hässig J et al (2011) Holznutzungspotentiale im Schweizer Wald. Auswertung der Nutzungsszenarien und Waldwachstumsentwicklung. 80

Kapeller S, Lexer MJ, Geburek T et al (2012) Intraspecific variation in climate response of Norway spruce in the eastern Alpine range: Selecting appropriate provenances for future climate. For Ecol Manag 271:46-57. doi:10.1016/j.foreco.2012.01.039

Kaufmann E (2001a) Prognosis and management scenarios. In: Brassel $\mathrm{P}$, Lischke $\mathrm{H}$ (eds) Swiss national forest inventory methods models second assess. Swiss Federal Research Institute WSL, Birmensdorf, pp 197-206

Kaufmann E (2001b) Estimation of standing timber, growth and cut. In: Brassel P, Lischke H (eds) Swiss national forest inventory methods models second assess. Swiss Federal Research Institute WSL, Birmensdorf, pp 162-197

Kaufmann E (2011) Nachhaltiges Holzproduktionspotenzial im Schweizer Wald. Schweiz Z Forstwes 162:300-311. doi:10. 3188/szf.2011.0300

Kautz M, Dworschak K, Gruppe A, Schopf R (2011) Quantifying spatio-temporal dispersion of bark beetle infestations in epidemic and non-epidemic conditions. For Ecol Manag 262:598-608. doi:10.1016/j.foreco.2011.04.023

Kläy M (2015) Economic situation of forest enterprises. Forest report 2015 condition and use Swiss forest. Swiss Federal Office for the Environment FOEN, Bern, and Swiss Federal Institute for Forest, Snow and Landscape Reseach WSL, Birmensdorf, pp 106-107

Köhl M (2001) Inventory concept NFI2. In: Brassel P, Lischke H (eds) Swiss national forest inventory methods models second assess. Swiss Federal Research Institute WSL, Birmensdorf, pp 19-46

Kraft U (2015) Wood end use. Forest report 2015 condition use Swiss forest. Swiss Federal Office for the Environment FOEN, Bern, and Swiss Federal Institute for Forest, Snow and Landscape Reseach WSL, Birmensdorf, pp 114-115

Krumm F, Kulakowski D, Risch A et al (2012) Stem exclusion and mortality in unmanaged subalpine forests of the Swiss Alps. Eur J For Res 131:1571-1583. doi:10.1007/s10342-012-0625-6

Kupferschmid AD, Bugmann H (2005) Predicting decay and ground vegetation development in Picea abies snag stands. Plant Ecol 179:247-268. doi:10.1007/s11258-005-0903-1

Lassauce A, Paillet Y, Jactel H, Bouget C (2011) Deadwood as a surrogate for forest biodiversity: meta-analysis of correlations between deadwood volume and species richness of saproxylic organisms. Ecol Indic 11:1027-1039. doi:10.1016/j.ecolind. 2011.02.004

Lauri P, Kallio AMI, Schneider UA (2012) Price of $\mathrm{CO}_{2}$ emissions and use of wood in Europe. For Policy Econ 15:123-131. doi:10. 1016/j.forpol.2011.10.003 
Lévesque M, Saurer M, Siegwolf R et al (2013) Drought response of five conifer species under contrasting water availability suggests high vulnerability of Norway spruce and European larch. Glob Change Biol 19:3184-3199. doi:10.1111/gcb.12268

Maroschek M, Rammer W, Lexer MJ (2014) Using a novel assessment framework to evaluate protective functions and timber production in Austrian mountain forests under climate change. Reg Environ Change 15:1543-1555. doi:10.1007/ s10113-014-0691-z

Nabuurs G-J, Delacote P, Ellison D et al (2015) A new role for forests and the forest sector in the EU post-2020 climate targets. From Science to Policy 2. European Forest Institute

Økland B, Nikolov C, Krokene P, Vakula J (2016) Transition from windfall- to patch-driven outbreak dynamics of the spruce bark beetle Ips typographus. For Ecol Manag 363:63-73. doi:10.1016/ j.foreco.2015.12.007

Pasztor F, Matulla C, Rammer W, Lexer MJ (2014) Drivers of the bark beetle disturbance regime in Alpine forests in Austria. For Ecol Manag 318:349-358. doi:10.1016/j.foreco.2014.01.044

Pfister C (1999) Wetternachhersage. 500 Jahre Klimavariationen und Naturkatastrophen (1496-1995). Verlag P. Haupt, Bern

Pretzsch H, Grote R, Reineking B et al (2008) Models for forest ecosystem management: a European perspective. Ann Bot 101:1065-1087. doi:10.1093/aob/mcm246

Primicia I, Camarero JJ, Janda P et al (2015) Age, competition, disturbance and elevation effects on tree and stand growth response of primary Picea abies forest to climate. For Ecol Manag 354:77-86. doi:10.1016/j.foreco.2015.06.034

Rammer W, Brauner M, Ruprecht H, Lexer MJ (2015) Evaluating the effects of forest management on rockfall protection and timber production at slope scale. Scand J For Res 30:719-731. doi:10. 1080/02827581.2015.1046911

Rasche L, Fahse L, Bugmann H (2013) Key factors affecting the future provision of tree-based forest ecosystem goods and services. Clim Change 118:579-593. doi:10.1007/s10584-0120664-5

Reyer C, Lasch-Born P, Suckow F et al (2014) Projections of regional changes in forest net primary productivity for different tree species in Europe driven by climate change and carbon dioxide. Ann For Sci 71:211-225. doi:10.1007/s13595-013-0306-8

Reyer CPO, Bathgate S, Blennow K et al (2017) Are forest disturbances amplifying or canceling out climate changeinduced productivity changes in European forests? Environ Res Lett 12:034027. doi:10.1088/1748-9326/aa5ef1

Rigling A, Frank D, Dobbertin M et al (2014) Jahrringanalysen entlang von Höhengradienten. In: Wohlgemuth T, Rigling A (eds) Kurz- Langfristige Auswirkungen Klimas Auf Wäld. Im Churer Rheintal. WSL Berichte 17, Eidg. Forschungsanstalt WSL, Birmensdorf, pp 20-40

Rohner B, Weber P, Thürig E (2016) Bridging tree rings and forest inventories: how climate effects on spruce and beech growth aggregate over time. For Ecol Manag 360:159-169. doi:10.1016/ j.foreco.2015.10.022

Royo AA, Carson WP (2006) On the formation of dense understory layers in forests worldwide: consequences and implications for forest dynamics, biodiversity, and succession. Can J For Res 36:1345-1362. doi:10.1139/x06-025

Schmid U, Bircher N, Bugmann H (2015) Naturnaher und multifunktionaler Waldbau in Zeiten des Klimawandels - eine Fallstudie. Schweiz Z Forstwes 166:314-324. doi:10.3188/szf. 2015.0314

Seidl R, Rammer W, Lexer MJ (2011a) Adaptation options to reduce climate change vulnerability of sustainable forest management in the Austrian Alps. Can J For Res 41:694-706. doi:10.1139/x10235
Seidl R, Rammer W, Lexer MJ (2011b) Climate change vulnerability of sustainable forest management in the Eastern Alps. Clim Change 106:225-254. doi:10.1007/s10584-010-9899-1

Seidl R, Schelhaas M-J, Lexer MJ (2011c) Unraveling the drivers of intensifying forest disturbance regimes in Europe. Glob Change Biol 17:2842-2852. doi:10.1111/j.1365-2486.2011.02452.x

Selva (2016) Rundholzpreise Graubünden. Bündner Waldwirtschaftsverband. http://www.selva-gr.ch. Accessed 24 Mar 2016

Stadelmann G, Bugmann H, Wermelinger B, Bigler C (2014) Spatial interactions between storm damage and subsequent infestations by the European spruce bark beetle. For Ecol Manag 318:167-174. doi:10.1016/j.foreco.2014.01.022

Stadelmann G, Temperli C, Conedera M et al (2015) Möglichkeiten zur Holzmobilisierung im Tessiner Kastaniengürtel. Schweiz Z Forstwes 166:291-298. doi:10.3188/szf.2015.0291

Stadelmann G, Herold A, Didion M et al (2016) Holzerntepotenzial im Schweizer Wald: simulation von Bewirtschaftungsszenarien. Schweiz Z Forstwes 167:152-161. doi:10.3188/szf.2016.0152

Stierlin HR, Zinggeler J (2001) Terrestrial inventory. In: Brassel P, Lischke $\mathrm{H}$ (eds) Swiss national forest inventory methods models second assess. Swiss Federal Research Institute WSL, Birmensdorf, pp 65-87

Streit K, Wunder J, Brang P (2009) Slit-shaped gaps are a successful silvicultural technique to promote Picea abies regeneration in mountain forests of the Swiss Alps. For Ecol Manag. doi:10. 1016/j.foreco.2008.12.018

Temperli C, Bugmann H, Elkin C (2013a) Cross-scale interactions among bark beetles, climate change, and wind disturbances: a landscape modeling approach. Ecol Monogr 83:383-402. doi:10. 1890/12-1503.1

Temperli C, Zell J, Bugmann H, Elkin C (2013b) Sensitivity of ecosystem goods and services projections of a forest landscape model to initialization data. Landsc Ecol 28:1337-1352. doi:10. 1007/s10980-013-9882-0

Thom D, Rammer W, Seidl R (2017) Disturbances catalyze the adaptation of forest ecosystems to changing climate conditions. Glob Change Biol 23:269-282. doi:10.1111/gcb.13506

Thürig E, Kaufmann E (2010) Increasing carbon sinks through forest management: a model-based comparison for Switzerland with its Eastern Plateau and Eastern Alps. Eur J For Res 129:563-572. doi:10.1007/s10342-010-0354-7

Thürig E, Kaufmann E, Frisullo R, Bugmann H (2005a) Evaluation of the growth function of an empirical forest scenario model. For Ecol Manag 204:53-68. doi:10.1016/j.foreco.2004.07.070

Thürig E, Palosuo T, Bucher J, Kaufmann E (2005b) The impact of windthrow on carbon sequestration in Switzerland: a modelbased assessment. For Ecol Manag 210:337-350. doi:10.1016/j. foreco.2005.02.030

Traub B, Meile R, Speich S, Rösler E (2017) The data storage and analysis system of the Swiss National Forest Inventory. Comput Electron Agric 132:97-107. doi:10.1016/j.compag.2016.11.016

Usbeck T, Wohlgemuth T, Dobbertin M et al (2010) Increasing storm damage to forests in Switzerland from 1858 to 2007. Agric For Meteorol 150:47-55. doi:10.1016/j.agrformet.2009.08.010

Vanoni M, Bugmann H, Nötzli M, Bigler C (2016) Quantifying the effects of drought on abrupt growth decreases of major tree species in Switzerland. Ecol Evol 6:3555-3570. doi:10.1002/ece3.2146

Wastl C, Schunk C, Leuchner M et al (2012) Recent climate change: long-term trends in meteorological forest fire danger in the Alps. Agric For Meteorol 162-163:1-13. doi:10.1016/j.agrformet. 2012.04.001

Wehrli A, Dorren LKA, Berger F et al (2006a) Modelling long-term effects of forest dynamics on the protective effect against rockfall. For Snow Landsc Res 80:57-76 
Wehrli A, Weisberg PJ, Schönenberger W et al (2006b) Improving the establishment submodel of a forest patch model to assess the long-term protective effect of mountain forests. Eur J For Res 126:131-145. doi:10.1007/s10342-006-0142-6

Wermelinger B, Schneider Mathis D (2014) Befallsrisiko von Waldföhren durch Borkenkäfer. In: Wohlgemuth T, Rigling A (eds) Kurz- Langfristige Auswirkungen Klimas Auf Wäld. Im Churer Rheintal. WSL Berichte 17, Eidg. Forschungsanstalt WSL, Birmensdorf, pp 49-57
Werner F, Taverna R, Hofer P et al (2010) National and global greenhouse gas dynamics of different forest management and wood use scenarios: a model-based assessment. Environ Sci Policy 13:72-85. doi:10.1016/j.envsci.2009.10.004

Wilhelm C, Kalberer M, Meier A (2011) Neuer Schutzwald Graubünden 2012. Bündner Wald 1:88-95 